University of Montana

ScholarWorks at University of Montana

2010

\title{
Testing Assumptions of Distance Sampling on a Pelagic Seabird
}

Paul M. Lukacs

University of Montana - Missoula, paul.lukacs@umontana.edu

Michelle L. Kissling

Mason Reid

Scott M. Gende

Stephen B. Lewis

Follow this and additional works at: https://scholarworks.umt.edu/wildbio_pubs

Part of the Life Sciences Commons

Let us know how access to this document benefits you.

\section{Recommended Citation}

Lukacs, Paul M.; Kissling, Michelle L.; Reid, Mason; Gende, Scott M.; and Lewis, Stephen B., "Testing Assumptions of Distance Sampling on a Pelagic Seabird" (2010). Wildlife Biology Faculty Publications.

69.

https://scholarworks.umt.edu/wildbio_pubs/69

This Article is brought to you for free and open access by the Wildlife Biology at ScholarWorks at University of Montana. It has been accepted for inclusion in Wildlife Biology Faculty Publications by an authorized administrator of ScholarWorks at University of Montana. For more information, please contact scholarworks@mso.umt.edu. 


\title{
TESTING ASSUMPTIONS OF DISTANCE SAMPLING ON A PELAGIC SEABIRD
}

\author{
Paul M. Lukacs ${ }^{1,6}$, Michelle L. Kissling ${ }^{2}$, Mason Reid ${ }^{3,7}$, Scott M. Gende ${ }^{4}$, \\ AND STEPHEN B. LeWIS ${ }^{5}$ \\ ${ }^{1}$ Colorado Division of Wildlife, 317 W. Prospect Rd., Fort Collins, CO 80526 \\ ${ }^{2}$ U.S. Fish and Wildlife Service, 3000 Vintage Blvd., Suite 201, Juneau, AK 99801 \\ ${ }^{3}$ Wrangell-St. Elias National Park and Preserve, P. O. Box 439, Copper Center, AK 99573 \\ ${ }^{4}$ National Park Service, Glacier Bay Field Station, 3100 National Park Road, Juneau, AK 99801 \\ ${ }^{5}$ Alaska Department of Fish and Game, Division of Wildlife Conservation, P. O. Box 110024, Juneau, AK 99824
}

\begin{abstract}
Distance sampling along a line transect is used commonly for monitoring changes of birds' abundance at sea. A critical yet rarely tested assumption of line-transect-sampling theory is that all birds along the transect line (i.e., directly in front of the boat) are detected or that probability of detecting a bird on the line can be estimated. As part of a long-term research and monitoring program for the Kittlitz's Murrelet (Brachyramphus brevirostris), we tested the assumption of complete detection of murrelets on the water along a transect line directly in front of a moving boat. Following standard survey procedures, we approached groups of murrelets $(n=57)$ at sea and recorded their distance, response (diving or flying), and duration of response. Flying murrelets $(n=27)$ were easily detected, but diving birds $(n=30)$ were more difficult to detect because of the duration of their dive. The probability that a bird dove and remained underwater long enough to avoid detection was low because birds that dove more than $150 \mathrm{~m}$ from the boat surfaced before the boat passed whereas birds that "waited" to dive near the boat were easily detected prior to diving. The greatest probability of nondetection was for birds diving at $55 \mathrm{~m}$ (diving long enough for the boat to pass) but was only $0.032 \pm 0.007(P+\mathrm{SE})$. These experiments quantifying detection probability along the transect line could be applied to any species surveyed from a boat.
\end{abstract}

Key words: Brachyramphus brevirostris, detection probability; distance sampling; Kittlitz's Murrelet; line-transect sampling; seabirds.

\section{Probando los Supuestos del Muestreo con Distancias en un Ave Pelágica}

Resumen. El muestreo con distancias a lo largo de un transecto es usado frecuentemente para monitorear cambios en la abundancia de aves en ambientes marinos. Un supuesto crítico pero raramente puesto a prueba de la teoría de muestreo en transectos lineales es que todas las aves sobre la línea del transecto (i.e., directamente enfrente del barco) son detectadas o que la probabilidad de detectar un ave en la línea puede ser estimada. Como parte de un programa de monitoreo e investigación de largo plazo para Brachyramphus brevirostris, probamos el supuesto de detección completa sobre el agua a lo largo de la línea justamente enfrente del barco en movimiento. Siguiendo procedimientos de muestreo estándar, nos acercamos a los grupos de B. brevirostris en el mar $(n=57)$ y registramos sus distancias, la respuesta (buceando o volando) y la duración de la respuesta. Los individuos que se encontraban volando $(n=27)$ fueron detectados fácilmente, pero los individuos que estaban buceando $(n=30)$ fueron más difíciles de detectar debido a la duración del buceo. La probabilidad de que un individuo buceara y que permaneciera sumergido por un tiempo suficientemente largo para no ser detectado fue baja porque las aves que bucearon a más de $150 \mathrm{~m}$ del bote salieron a la superficie de nuevo antes de que el barco pasara, mientras que las aves que "esperaron" para bucear cerca del barco fueron detectadas fácilmente antes de que se sumergieran. La mayor probabilidad de falta de detección fue para aves que bucearon a $55 \mathrm{~m}$ del barco (i.e., que bucearon por un tiempo suficientemente para que el barco pasara sobre ellas), pero ésta fue de sólo $0.032 \pm 0.007(P+\mathrm{EE})$. Estos experimentos que cuantifican la probabilidad de detección a lo largo de la línea del transecto podrían ser aplicados a cualquier especie muestreada desde un barco.

\section{INTRODUCTION}

Boat-based surveys are the most common approach to monitoring populations of marine birds at sea. For a monitoring program to be successful, it is important that assumptions used in the sampling methods are valid and achievable, or else faulty inferences may be drawn about the population in question. The need for valid assumptions is particularly important for declining populations for which abundance estimates may trigger critical and potentially costly management.

Manuscript received 26 October 2009; accepted 31 March 2010.

6E-mail: paul.lukacs@state.co.us

${ }^{7}$ Current address: Mt. Rainier National Park, 55210-238th Ave. E., Ashford, WA 39304-9751

The Condor, Vol. 112, Number 3, pages 455-459. ISSN 0010-5422, electronic ISSN 1938-5422. @ 2010 by The Cooper Ornithological Society. All rights reserved. Please direct all requests for permission to photocopy or reproduce article content through the University of California Press's Rights and Permissions website, http://www.ucpressjournals.com/ reprintInfo.asp. DOI: 10.1525/cond.2010.090204 
The Kittlitz's Murrelet (Brachyramphus brevirostris) is a rare noncolonial seabird that spends most of its time at sea. To date, efforts at monitoring have yielded relatively imprecise estimates of abundance, but the ubiquity of declines in the core population areas has resulted in the species' being given a "candidate 2" priority for listing under the Endangered Species Act (73 FR 75914). Causal factors driving the decline have not yet been rigorously identified; monitoring must be sufficiently precise and powerful to ascertain whether efforts at management and conservation are effective.

Given the noted decline, Kissling et al. (2007) designed a long-term monitoring program to track the abundance of Kittlitz's Murrelet in Icy Bay, southeastern Alaska, an area that supports a significant fraction of the world's known population of the species (USFWS 2007). The foundation of the program is distance sampling along a line transect, under the assumption that all birds on the transect line directly in front of the boat (at zero perpendicular distance) are detected or that the portion of birds detected on the line can be estimated (Buckland et al. 2001). Yet violation of this assumption is possible because murrelets may dive or fly in response to a disturbance such as an approaching survey boat (Agness et al. 2008). In a test of probability of detection on the transect line for the Marbled Murrelet (B. marmoratus), a species very similar to Kittlitz's Murrelet, Evans Mack et al. (2002) showed that detection probability at zero distance, even with two observers, is not complete $(<85 \%)$.

Failing to detect a murrelet on the transect line results from a series of conditional events. First, the bird must be on the line. Although murrelets off the transect line can be missed, the probability of nondetection can be estimated by the detection function for distance sampling. Therefore, we focused on testing the assumption that birds on the transect line are detected. Second, for a murrelet, flight from the water is obvious, involving a long, splashing scurry across the surface before liftoff. However, the birds dive very quickly, leaving little more than a ring of ripples on the surface of the water, and are thus far more likely to be missed by the observer. We therefore focus on detection probability when murrelets dive in response to the boat. Third, to go undetected, a bird must remain underwater long enough for the boat to pass over it, which is a dynamic function of the distance from the boat at which the dive was initiated, the bird's duration under water (dive time), and boat speed. Undisturbed Kittlitz's Murrelet have been recorded diving for about $29 \mathrm{sec}$ on average (with considerable variability among dives; Day et al. 1999), so a murrelet that dives far from the boat is likely to resurface prior to the boat passing, while one that dives close to the boat is more likely to have the boat pass over it.

In this study, we tested the assumption that all Kittlitz's Murrelets are detected on the transect line by quantifying the proportion of times a murrelet dives in response to an approaching vessel, the distance at which the response occurs, and the duration of the dive.

\section{METHODS}

Our study was conducted in Icy Bay, Alaska $\left(60^{\circ} 01^{\prime} \mathrm{N}\right.$, $141^{\circ} 20^{\prime} \mathrm{W} ; 110 \mathrm{~km}$ northwest of Yakutat, Alaska). To examine the detectability of Kittlitz's Murrelet on the transect line, we mimicked the distance-sampling protocol described by Kissling et al. (2007) as closely as possible but in a more controlled setting, in which we knew the location of an individual murrelet prior to conducting the trial. We used the same 5.5-m boat and three-person sampling crew for these trials as for the Kittlitz's Murrelet monitoring. The sampling crew consisted of two observers, one on each side of the boat, and one boat driver.

We located one or more Kittlitz's Murrelets that were a long distance $(>300 \mathrm{~m})$ from the boat and that visually appeared undisturbed. To ensure they appeared undisturbed, we took time to spot these birds from a longer distance than could be done during the active survey described by Kissling et al. (2007). We approached bird(s) at survey speed $\left(10 \mathrm{~km} \mathrm{hr}^{-1}\right.$, 5.4 knots) as if they were on the transect line, defined as directly in front of the boat at the start of the approach, and recorded the distance (m) from the boat to the bird at the time of its response. We trained observers on distance estimation with laser range finders and periodically checked their accuracy. In addition to distance, we also recorded type of response (dove or flew), and number of Kittlitz's Murrelets in the group. If the bird(s) dove in response to the boat, we recorded time underwater (sec) and behavior when the bird(s) resurfaced (e.g., dove again, flew). Groups of murrelets tended to be small, and variation in the birds' plumage allowed individuals to be tracked if more than one bird in a group dove. If at least one bird in a group dove, the event was considered a dive because there was a possibility of failure to detect the diving bird even if other birds in the group were detected.

To estimate the probability of detecting a bird at given distance from the boat, we applied the distance-sampling detection function estimated from Kittlitz's Murrelet abundance surveys previously analyzed by Kissling et al. (2007) (Fig. 1). We reasoned that the probability of detection at varying distances in front of the boat should be similar to that at the same distances perpendicular to the boat. The distance-sampling data used to estimate the detection function consisted of 72 transects surveyed and 261 groups of murrelets detected with an average group size of $1.86 \pm 0.04$ (SE) birds per group. The selected detection function was a half-normal function (Buckland et al. 2001).

\section{STATISTICAL ANALYSES}

We used logistic regression to estimate the probability that a murrelet dove as linear and quadratic functions of distance from the approaching boat. We used AIC $c$ to select between the two logistic-regression models (Burnham and Anderson 2002). We then computed the conditional probability of dive duration, 


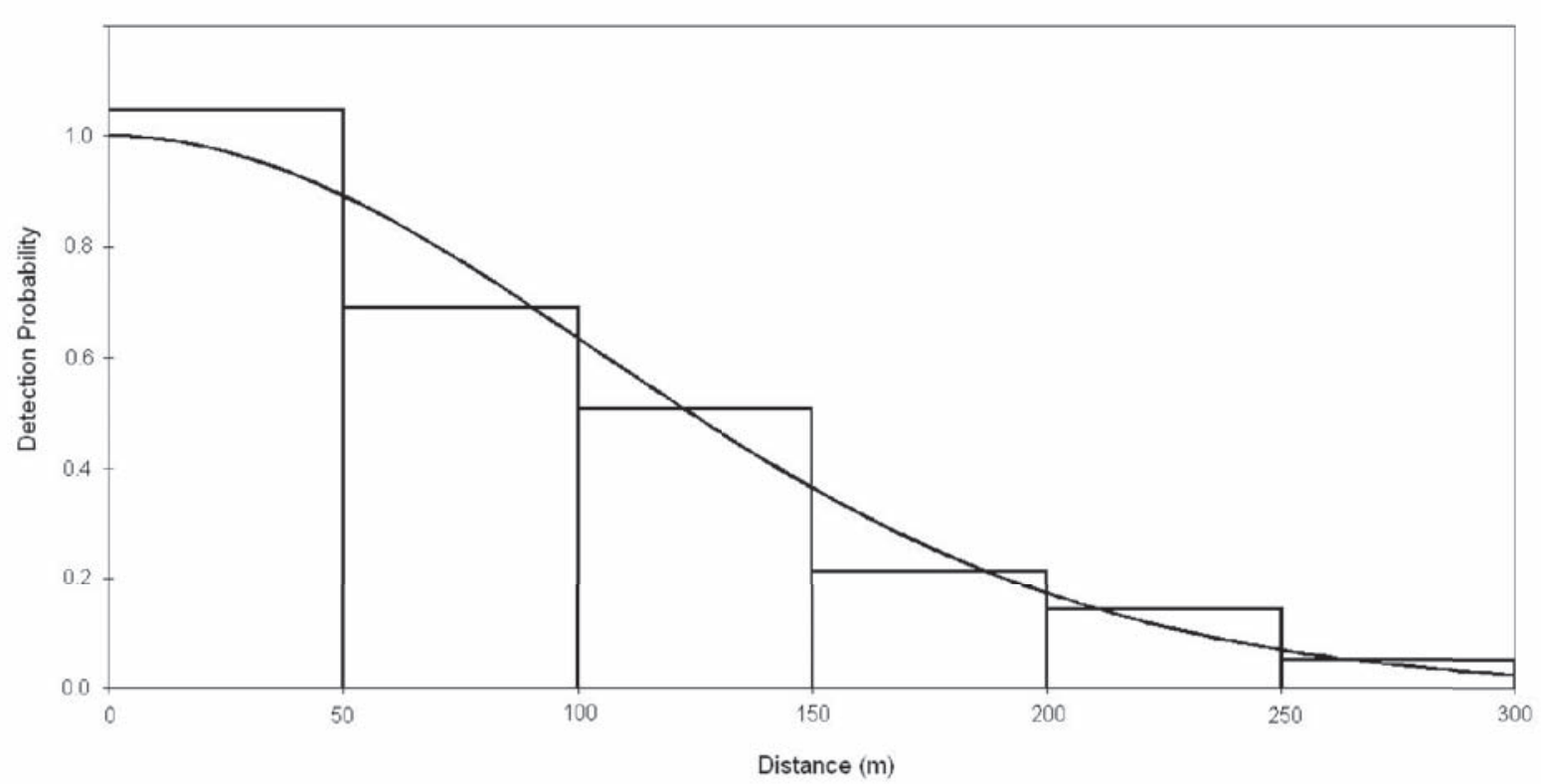

FIGURE 1. Estimated detection function and histogram of detections by distance for a survey of Kittlitz's Murrelets in Icy Bay, Alaska, from data in Kissling et al. (2007).

given that a bird dove (computed as the count of birds diving longer than $x$ seconds divided by the number of birds that dove).

We calculated the probability that a bird was undetected, dove, and remained underwater long enough to allow the boat to pass it as

$$
\begin{aligned}
& \operatorname{Pr}[\text { not detected on transect } \mid x]= \\
& \quad(1-\operatorname{Pr}[\text { detect } \mid x]) \operatorname{Pr}[\text { drive } \mid x] \operatorname{Pr}[\text { drive }>t \mid x]
\end{aligned}
$$

where $\operatorname{Pr}[\operatorname{detect} \mid x]$ is the detection probability at distance $x$ estimated from the fitted distance-sampling detection function (Fig. 1, Kissling et al. 2007), $\operatorname{Pr}[$ dive $\mid x$ ] is the probability that a murrelet dives in response to the boat at distance $x$, and $\operatorname{Pr}[$ dive $>t \mid x]$ is the probability that a bird remains underwater for more than the time it takes the boat to pass it $(t \mathrm{sec})$. We computed the variance of $\operatorname{Pr}[$ not detected on transect] by the delta method (Williams et al. 2002, Powell 2007). All analyses were performed in R version 2.6.1 (R Development Core Team 2008).

\section{RESULTS}

During our trials to test detectability on the transect line, we approached 57 individual birds or groups. In response, Kittlitz's Murrelets were almost equally likely to dive (30 dives; $53 \%$ ) as to fly ( $47 \%$ of responses), although the response varied as a function of distance. A quadratic logistic-regression model of the probability that the response was a dive was favored over the linear model $\left(\Delta \mathrm{AIC}_{c}=2.46\right.$; Fig. 2$)$. Birds very close to the boat or $>150 \mathrm{~m}$ from the boat were more likely to fly, while birds within $50-150 \mathrm{~m}$ of the boat were more likely to dive, although the probability of response at farther distances was imprecisely estimated.

The average duration of all escape dives was $17.4 \mathrm{sec} \pm$ 6.9 (SD), approximately the same time our boat traveled $50 \mathrm{~m}$. A linear regression of dive time as a function of distance from

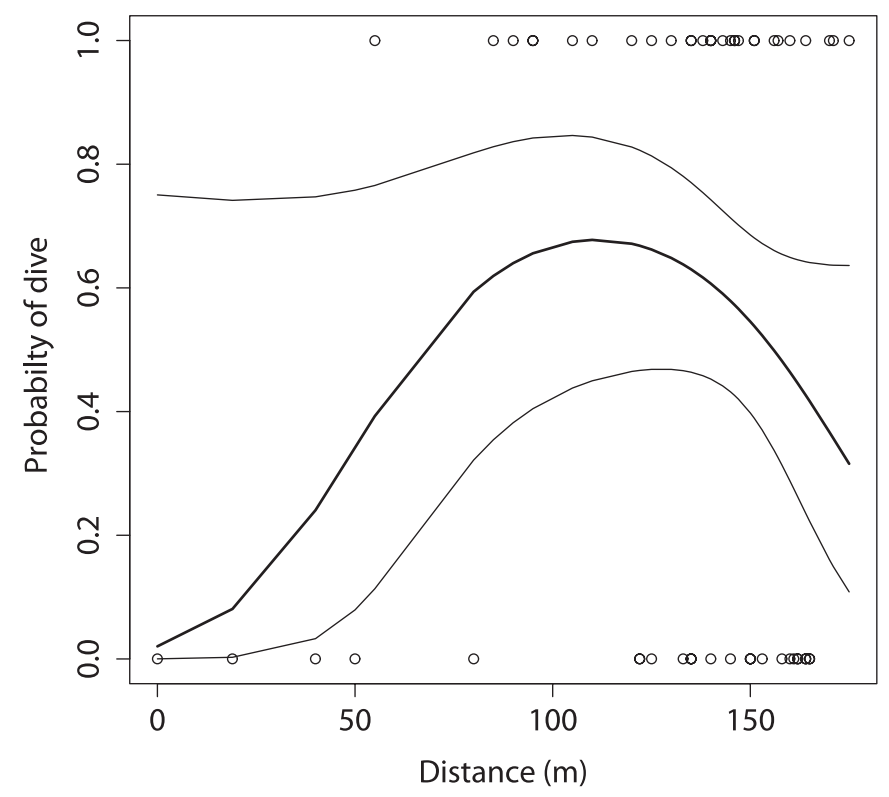

FIGURE 2. Fitted quadratic logistic regression of the probability of a Kittlitz's Murrelet diving given its distance to an approaching boat. Circles represent dive response $($ dive $=1)$, lines represent the mean and $95 \%$ confidence interval of the model. 


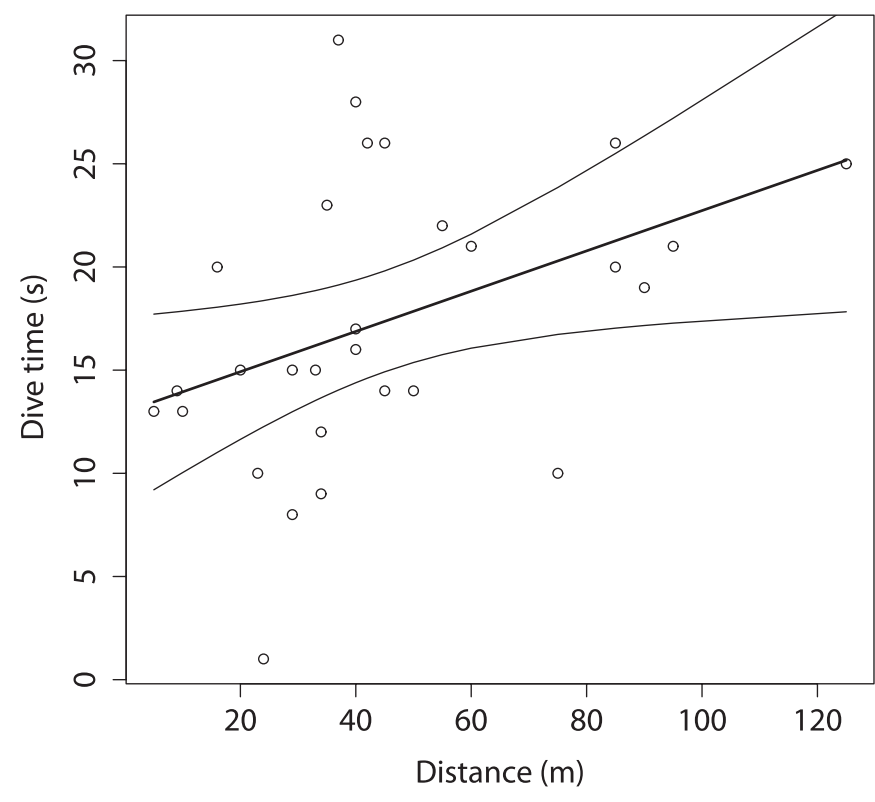

FIGURE 3. Fitted linear regression model of Kittlitz's Murrelet dive time (sec) as a function of distance to an approaching boat. Circles represent the data and lines represent the mean and 95\% confidence interval of the model.

the approaching boat shows dive time increasing as distance increases (Fig. 3). The model predicted that when the bird dove $50 \mathrm{~m}$ from the boat, dive time was $17.9 \mathrm{sec}$.

Applying the probability of a dive to the dive times and our boat's average speed $\left(10 \mathrm{~km} \mathrm{hr}^{-1}\right.$ or $\left.2.78 \mathrm{~m} \mathrm{sec}^{-1}\right)$ demonstrated that the probability of missing a murrelet on the transect line varied as a function of distance from the boat but was quite low (Fig. 4). The probability of failing to detect a murrelet was highest when a dive was initiated $55 \mathrm{~m}$ ahead of the boat, although this probability was only $0.032 \pm$ $0.006(\mathrm{SE})$.

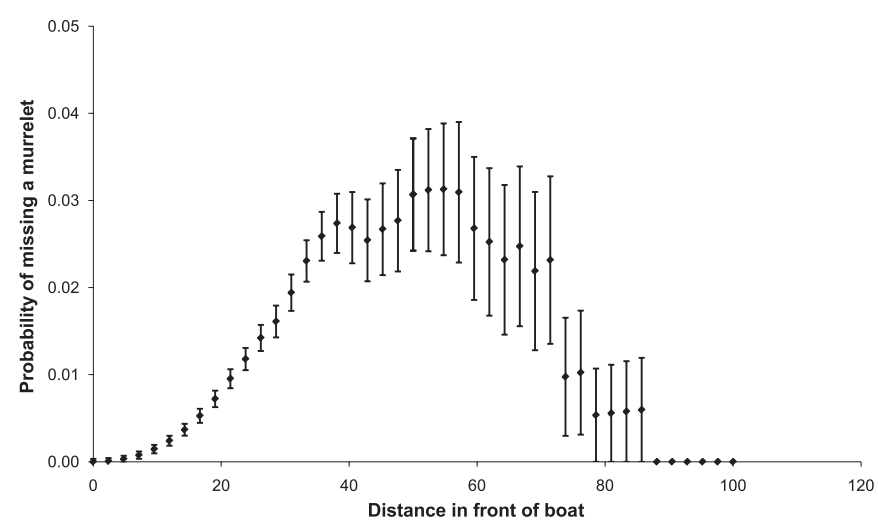

FIGURE 4. Probability of failing to detect a Kittlitz's Murrelet that dives in response to a boat as a function of distance from the approaching boat.

\section{DISCUSSION}

Defensible monitoring programs must be based on assumptions that can be tested and are realistic. Although well-designed probability-based designs can be fairly free of assumptions, the methods used to detect birds in a sampling unit almost always require model-based assumptions about the detection process (i.e., distance sampling, mark-recapture, double observer). Distance sampling and other vessel-based transect surveys are common for a variety of seabirds (Becker and Beissinger 1997, Spear et al. 2004, Ronconi and Burger 2009).

Tests of seabird detectability routinely demonstrate that if the transect strip is wide, detection probability is less than 1 (Spear et al. 2004, Kissling et al 2007). For line-transect distance sampling, the width of the strip within which the probability of detection is assumed to be 1 is very narrow, so the focus of attention for violations of assumptions also becomes narrow.

The potential for a violation of complete detection along the line transect exists for any species. Bächler and Liechti (2007) highlighted the general need for testing the assumption of complete detection at zero distance and showed detection $<1$ at zero distance with point-transect data on the Orphean Warbler (Sylvia hortensis). This assumption has received considerable attention in the literature on the Marbled Murrelet, which is commonly surveyed at sea with distance-sampling methods very similar to ours with Kittlitz's Murrelet. Evans Mack et al. (2002) demonstrated detection $<1$ on the transect line with Marbled Murrelets. Ronconi and Burger (2009) also showed that detection of Marbled Murrelets on the transect line may be $<1$. Therefore, sufficient evidence exists to warrant regular testing of the assumption of complete detection on the transect line.

The distance-sampling protocol developed for Kittlitz's Murrelet assumes detection on the transect line directly in front of the boat is certain (Kissling et al. 2007), and our results suggest that this assumption is largely upheld. The highest probability of an individual being missed was only 0.032 , and at most distances $(<40 \mathrm{~m}$ and $>60 \mathrm{~m}$ from the boat) the probability of a murrelet being missed, given it flies or dives, at was considerably less. The average probability of a murrelet on the transect line being missed is $<0.03$.

Methods exist to directly estimate detection on the transect line during distance sampling and therefore relax the assumption of complete detection (Buckland et al. 2004). These methods include the use of two observers both watching for birds on the transect line (Borchers et al. 1998, Evans Mack et al. 2002). While we had two observers on our boat, the independent-double-observer method was impractical because each observer was positioned on one side of the boat and was responsible for all detections on that side. Moreover, because of the design of the boat, observers are close together and each can hear and see what the other is doing. Therefore, it would not be possible for observers to act independently when 
detecting birds in front of the boat. The boat driver was occupied with avoiding obstacles such as floating ice and therefore not a reliable additional observer.

Our results for Kittlitz's Murrelet suggest we detected a higher proportion of birds on the transect line than reported for the Marbled Murrelets by Evans Mack et al. (2002). It is possible that the difference in boat speed (we traveled half as fast) may account for some of the difference. Also, differences between the two species' behavior likely contributed to the difference in detection probability. The difference in detection-probability estimates does highlight the need for assumptions to be evaluated on a case-by-case basis.

In our analysis, we made two important assumptions that should be noted. First, we assumed that the detection function estimated by Kissling et al. (2007) for perpendicular distance applied to birds in front of the boat. This assumption implies that detection at zero distance is 1 . Violating this assumption would influence the $y$ intercept of the model more than the shape. We believe that a bird on the water (not diving) would be detected with certainty because the boat would hit the bird if it were not detected. The more critical test is for birds that are underwater and therefore unavailable for detection - the issue we evaluated in this study. Dive times varied as a function of the bird's distance from the boat. The difference may be a result of birds diving to forage when far from the boat and diving to avoid the boat when nearby. Our analysis accounted for this variation. Second, we assumed we detect murrelets before they move toward or away from the boat. We had no way to test this assumption with our data.

Our Kittlitz's Murrelet approach trials were a useful surrogate for estimating detection on a transect line during the survey. Murrelets appeared undisturbed prior to the trial, and our approach with the boat closely mimicked actual survey transects. Therefore, we do not think that the birds' reactions differed from those during a survey. Using this more controlled approach we were able to track closely the behavior of the birds before and after they responded to the boat so that we could record specific details such as distance from the boat to the diving bird and dive time. Dive time could not have been recorded during an actual survey because of the need to focus on detecting and counting birds. We are confident that our identifications of individuals pre- and post-dive were correct because group size was low $(\bar{x}=1.85$ birds $)$ and variation in the breeding plumage of Kittlitz's Murrelet is large (Day et al. 1999), easing recognition of individuals. Therefore, the dive times we report are reliable. During actual surveys, observers are required to continue looking for new birds and do not have time to track birds that dive.

Although our results showed that the assumption of complete detection along the transect line was valid for our surveys, this assumption might not be valid for all surveys at sea. We recommend that researchers test this assumption for their particular species and conditions.

\section{ACKNOWLEDGMENTS}

We thank the National Park Service and U.S. Fish and Wildlife Service for funding and logistical support. We are grateful to Daniel Harrington for his superior assistance in the field and George and Jill Davis for their hospitality and watchful eye. Alsek Air and Yakutat Coastal Airlines provided support in the field.

\section{LITERATURE CITED}

Agness, A. M., J. F. Piatt, J. C. Ha, and G. R. Van Blaricom. 2008. Effects of vessel activity on the near-shore ecology of Kittlitz's Murrelets (Brachyramphus brevirostris) in Glacier Bay, Alaska. Auk 125:346-353.

BÄChlER, E., AND F. LIECHTI. 2007. On the importance of $g(0)$ for estimating bird population densities with standard distancesampling: implications from a telemetry study and a literature review. Ibis 149:693-700.

Becker, B. H., AND S. R. Beissinger. 1997. At-sea density monitoring of Marbled Murrelets in central California: methodological considerations. Condor 99:743-755.

Borchers, D. L., S. T. Buckland, P. W. Goedhart, and E. D. CLARKE. 1998. Horvitz-Thompson estimators for double-platform line transect surveys. Biometrics 54:1221-1237.

Buckland, S. T., D. R. Anderson, K. P. Burnham, J. L. LaAke, D. L. Borchers, AND L. Thomas. 2001. Introduction to distance sampling: estimating abundance of biological populations. Oxford University Press, Oxford, UK.

Buckland, S. T., D. R. Anderson, K. P. Burnham, J. L. Laake, D. L. Borchers, AND L. ThOMAS. 2004. Advanced distance sampling: estimating abundance of biological populations. Oxford University Press, Oxford, UK.

DAY, R. H., D. J. Kuletz, AND D. A. NigRo. 1999. Kittlitz's Murrelet (Brachyramphus brevirostris), no. 435. In A. PoOle AND F. GILL [EDS.], The Birds of North America. Birds of North America, Inc., Philadelphia.

Evans Mack, D., M. G. Raphael, and J. L. LaAke. 2002. Probability of detecting Marbled Murrelets at sea: effects of single versus double observers. Journal of Wildlife Management 66:865873.

Kissling, M. K., M. Reid, P. M. Lukacs, S. M. Gende, and S. B. LEWIS. 2007. Understanding abundance patterns of a declining seabird: implications for monitoring. Ecological Applications 17:2164-2174.

Powell, L. A. 2002. Approximating variance of demographic parameters using the delta method: a reference for avian biologists. Condor 109:949-954.

R Development Core Team. 2008. R: a language and environment for statistical computing. R Foundation for Statistical Computing, Vienna, Austria.

RonCONI, R. A., AND A. E. Burger. 2009. Estimating seabird densities from vessel transects: distance sampling and implications for strip transects. Aquatic Biology 4:297-309.

Spear, L. B., D. G. Ainley, B. D. Hardesty, S. N. G. Howell, and S. W. WEBB. 2004. Reducing biases affecting at-sea surveys of seabirds: use of multiple observations. Marine Ornithology $32: 147-157$.

U. S. Fish and Wildlife Service. 2007. Kittlitz's Murrelet species assessment and listing priority assignment form. U.S. Fish and Wildlife Service, Anchorage, AK.

Williams, B. K., J. D. Nichols, And M. J. Conroy. 2002. Analysis and management of animal populations. Academic Press, San Diego. 